\title{
The Impact of Agro-well Development on Floral Diversity in Tank Cascades in the Dry Zone of Sri Lanka
}

\author{
Muditha Prasannajith Perera ${ }^{1}$, K.W.G. Rekha Nianthi ${ }^{2}$ \\ ${ }^{1,2}$ Department of Geography, University of Peradeniya, Sri Lanka
}

\begin{abstract}
The dry zone farmers of Sri Lanka have no choice but to sustain the perennial crops in the long dry period (common to the dry zone) without a use of supplementary irrigation or groundwater resources. The emergence of Agro-well based agricultural systems has been common to the North Central dry zone since the 1980s decade. There is a common believe that the Agro-well based land development projects have drastically changed the overall land use of tank cascades in the dry zone. With this contextual impression, a number of scientists emphasized that there would be serious issues on biodiversity of the cascades. But some of them emphasized that to prove this argument further research is essential. Accordingly, this floral survey has conducted and computed the Simpson's Diversity Index to compare the diversity impact between low Agro-well density and high Agro-well density cascades in the selected mini-basins of the dry zone. The results revealed that the floral diversity impacts were not at the significant level.
\end{abstract}

Keywords: Agro-wells, Floral diversity, Tank cascades, Dry zone.

\section{Introduction}

Groundwater exploration for the agricultural purposes of the dry zone of Sri Lanka was a reality, and "Agro-wells" were introduced in order to provide access to shallow groundwater. It was an attractive solution for the dry zone farmers to cultivate throughout the year. Since 1989, the expansion of Agro-wells was a recognized agenda for both Governmental and Non-Governmental Organizations [3]. The diffusion of Agro-wells in low land areas of river basins as well as within the "Tank Cascades" has been a significant level.

The dry zone river basins including mini basins of Sri Lanka consisted of complex tank systems from the $1^{\text {st }}$ century B.C. (Brohier, 1934) [1]. These tank systems have been identified as "Tank Cascade Systems" by Madduma Bandara (1985) [6]. After the Ratnatunga's (1970) [11] "Eco-Village" concept many studies started to describe the Ecological/Biological status of these tank systems. Madduma Bandara (2009) [7], and Dharmasena (2010) [5], revealed that the tank ecosystems play a vital role in the dry zone environment including the maintaining of biodiversity.

However, the Agro-well based land development in the vicinity of tanks has been increased very rapidly. The immediate changes of the tank cascade landscape due to Agro-well development may be a serious issue with the aspect on bio-diversity. Owing to the complex vegetation types in tank cascades, the diversity of both fauna and flora becomes generally high (Madduma Bandara 2009[7], Dharmasena 2010[5], Perera 2010[10]) as it provides a variety of food resources and resting and nesting/breeding sites. Degrading of flora and fauna communities, loss of fertile lands and destruction of the village ecosystems, are the most distinct factors that have affected the tank cascade systems of Sri Lanka. The most heavily affected areas are the use of traditional knowledge on conservation and sustainable utilization of biodiversity. The tank systems contribute to biodiversity and provide mixed, heterogenous landscapes: small tanks, irrigated paddy fields, forests, and villages (Marambe et al. 2012) [9].

Madduma Bandara (2009) [7], and Dharmasena (2010) [5] have explained that, the various development activities including Agro-well development, degrading of flora and fauna communities, loss of fertile lands, destruction of the village ecosystems, were the most distinct factors that have affected the tank cascade systems of Sri Lanka. Further, Marambe et al. (2012) [9] revealed that during the past few decades there has been a drastic reduction in forest cover and degrading of flora and fauna communities due to various development activities in tank cascades.

In view of that, the general opinion is the recent agricultural changes including Agro-well development have affected the floral diversity in tank cascade systems. Therefore, this study examined this perspective by comparing the floral diversity between high Agro-well density cascades and low Agro-well density cascades. Accordingly, the hypothesis of the current test was "Agro-well development causes the degradation of floral diversity in tank cascades".

\section{Methodology}

Conducted a floral survey and analyzed the diversity status using Simpson's Diversity Index. Among the floral category of 'Seedling, Sapling and Trees', the "Trees" ( $\mathrm{H}=>1 \mathrm{~m} \&$ $\mathrm{DBH}=>5 \mathrm{~cm}$ ) were selected for the current survey. The study was conducted covering two river basins namely; Malwathu Oya basin and the Yan Oya basin in the dry zone of Sri Lanka. A couple of tank cascades from two river basins were randomly selected considering similar resource conditions except the Agro-well density.

Table 1: Status of selected tank cascades from Malwathu Oya basin

Volume 5 Issue 6, June 2016 


\section{International Journal of Science and Research (IJSR) \\ ISSN (Online): 2319-7064}

Index Copernicus Value (2013): 6.14 | Impact Factor (2015): 6.391

\begin{tabular}{|c|c|c|}
\hline Category & $\begin{array}{c}\text { Halmillawewa tank } \\
\text { cascade (Agro-well } \\
\text { density-Low) }\end{array}$ & $\begin{array}{c}\text { Periyakulama tank } \\
\text { cascade (Agro-well } \\
\text { density-High) }\end{array}$ \\
\hline Residential families & 123 & 135 \\
\hline $\begin{array}{l}\text { Number of floral } \\
\text { lands use types }\end{array}$ & 7 & 7 \\
\hline $\begin{array}{l}\text { Agro-ecological } \\
\text { region }\end{array}$ & $\begin{array}{c}\text { DL } 1 \\
\text { (Dry low lands) } \\
\end{array}$ & $\begin{array}{c}\text { DL } 1 \\
\text { (Dry low lands) } \\
\end{array}$ \\
\hline Mean annual rainfall & $1250-1400 \mathrm{~mm}$. & $1250-1400 \mathrm{~mm}$. \\
\hline $\begin{array}{l}\text { Average depth to } \\
\text { bed rock }\end{array}$ & $6 \mathrm{~m}-6.5 \mathrm{~m}$ & $6 \mathrm{~m}-6.5 \mathrm{~m}$ \\
\hline $\begin{array}{c}\text { Average slope } \\
\text { pecentage }\end{array}$ & $1 \%$ & $1 \%$ \\
\hline Soil grade & $\begin{array}{l}\text { Medawachchiya- } \\
\text { Aluthwewa- } \\
\text { Divulwewa- } \\
\text { Hurathgama- } \\
\text { Kahatagasdigiliya- } \\
\text { Association } \\
\text { (No-37) }\end{array}$ & $\begin{array}{l}\text { Medawachchiya- } \\
\text { Aluthwewa- } \\
\text { Divulwewa- } \\
\text { Hurathgama- } \\
\text { Kahatagasdigiliya- } \\
\text { Association } \\
\text { (No-37) }\end{array}$ \\
\hline Agro-well density & $5.4 \mathrm{per} / \mathrm{km}^{2}$ & $22 \mathrm{per} / \mathrm{km}^{2}$ \\
\hline
\end{tabular}

Source: Agrarian service departmental documents and field study, 2013

Table 2: Status of selected tank cascades from Yan Oya basin

\begin{tabular}{|c|c|c|}
\hline Category & $\begin{array}{c}\text { Rambewewa tank } \\
\text { cascade } \\
\text { (Agro-well density- } \\
\text { Low) }\end{array}$ & $\begin{array}{c}\text { Belikulama } \\
\text { tankcascade } \\
\text { (Agro-well density- } \\
\text { High) }\end{array}$ \\
\hline Residential families & 46 & 39 \\
\hline $\begin{array}{l}\text { Number of floral } \\
\text { lands use types }\end{array}$ & 7 & 7 \\
\hline $\begin{array}{l}\text { Agro-ecological } \\
\text { region }\end{array}$ & $\begin{array}{c}\text { DL } 1 \\
\text { (Dry low lands) }\end{array}$ & $\begin{array}{c}\text { DL } 1 \\
\text { (Dry low lands) } \\
\end{array}$ \\
\hline Mean annual rainfall & $1250-1350 \mathrm{~mm}$. & $1250-1350 \mathrm{~mm}$. \\
\hline $\begin{array}{l}\text { Average depth to } \\
\text { bed rock }\end{array}$ & $6 \mathrm{~m}-6.5 \mathrm{~m}$ & $6 \mathrm{~m}-6.5 \mathrm{~m}$ \\
\hline $\begin{array}{c}\text { Average slope } \\
\text { percentage }\end{array}$ & $2 \%$ & $2 \%$ \\
\hline Soil grade & $\begin{array}{l}\text { Medawachchiya- } \\
\text { Aluthwewa- } \\
\text { Divulwewa- } \\
\text { Hurathgama- } \\
\text { Kahatagasdigiliya- } \\
\text { Association } \\
\text { (No-37) }\end{array}$ & $\begin{array}{l}\text { Medawachchiya- } \\
\text { Aluthwewa- } \\
\text { Divulwewa- } \\
\text { Hurathgama- } \\
\text { Kahatagasdigiliya- } \\
\text { Association } \\
\text { (No-37) }\end{array}$ \\
\hline Agro-well density & $1.1 \mathrm{Per} / \mathrm{km}^{2}$ & $19 \mathrm{Per} / \mathrm{km}^{2}$ \\
\hline
\end{tabular}

Source: Agrarian service departmental documents and field study 2012

The proportionate stratified sampling method (stratified sampling method according to the land percentage) was used for the data collection. These land categories were Riverine forest strips, Highland forest patches, Kattakaduwa, Gasgommana, Home gardens, Chena lands and Agro-well lands. The percentages of the floral/tree land uses were calculated except the tank water surface and paddy fields in each cascade. The sampling plot size was $400 \mathrm{~m}^{2}(20 \mathrm{~m}$ by $20 \mathrm{~m}$ ). However, practically it was difficult to find a $20 \mathrm{~m}$ by $20 \mathrm{~m}$ plots in riverine forest strips and Kattakaduwa tank reservation. Therefore, $400 \mathrm{~m}^{2}$ requirements were completed using $10 \mathrm{~m}$ by $40 \mathrm{~m}$ sample plots.
The tree survey was conducted (by a five-member group, including two senior farmers) to identify the common names of rare tree species. Some of the tree species with scientific names were identified with the help of the academics (biologists) of the Faculty of Agriculture, University of Peradeniya. The collected data of individual trees and number of species were analyzed to determine the status of floral diversity using the "Simpson's Diversity Index".

Simpson's Diversity Index (D)
\begin{tabular}{|l|}
\hline \\
$\mathrm{D}=\frac{\sum \mathrm{n}(\mathrm{n}-1)}{\mathrm{N}(\mathrm{N}-1)}$ \\
$\mathrm{l}-\mathrm{D}$ (The value of this index \\
ranges between 0 and 1 and the \\
greater value show the greater \\
sample diversity) \\
$\mathrm{n}=$ the total number of \\
organisms of a particular species \\
$\mathrm{N}=$ the total number of \\
organisms of all species
\end{tabular}

This method was used to identify the diversity status of high Agro-well density cascades and low Agro-well density cascades. Then the status of floral diversity of tank cascades was compared among the high Agro-well density cascades and low Agro-well density cascades in two river basins. Finally, a significant test was conducted to test the level of significance and to test the hypothesis.

\section{Results and Discussions}

\subsection{Status of the floral diversity - Malwathu Oya basin}

Halmillawewa cascade (Low Agro-well density $/ 5.4 \mathrm{per} / \mathrm{km}^{2}$ )

\begin{tabular}{l}
$D=\frac{\sum n(n-1)}{N(N-1)}$ \\
$S P_{5}=44$ \\
$N=213$ \\
$\sum n(n-1)=2802$ \\
$D=2802 / 213(212)$ \\
$D=2802 / 45,156$ \\
$D=0.062$ \\
$1-D=1-0.062$ \\
Diversity Index $=0.938$ \\
\hline
\end{tabular}

Periyakulama cascade (High Agro-well density $/ 22$ per $/ \mathrm{km}^{2}$ )

Volume 5 Issue 6, June 2016 www.ijsr.net 
International Journal of Science and Research (IJSR)

ISSN (Online): 2319-7064

Index Copernicus Value (2013): 6.14 | Impact Factor (2015): 6.391

\begin{tabular}{|l|}
$D=\frac{\sum n(n-1)}{N(N-1)}$ \\
$S P_{5}=47$ \\
$N=232$ \\
$\sum n(n-1)=4050$ \\
$D=4050 / 232(231)$ \\
$D=4050 / 53,592$ \\
$D=0.075$ \\
$1-D=1-0.075$ \\
Diversity Index $=0.925$ \\
\hline
\end{tabular}

In the Halmillawewa cascade (Low Agro-well density), 44 tree species and 213 individual trees have been identified. The diversity index was 0.938 . The reason for the higher diversity was the rich diversity level of the 'Gasgommana' and 'Highland forest patches'. 32\% and 30\% of the total species have been recorded from these land use types respectively.

In the Periyakulama cascade (High Agro-well density), 47 tree species and 232 individual trees have been recorded. The diversity index was 0.925. Although this cascade consisted of 144 Agro-wells, the reason for the higher diversity was high tree diversity in 'Agro-well lands'. 34\% of total species have been recorded in Agro-well lands. In addition to that, $32 \%$ of the total species recorded from the 'riverine forest strips'. Accordingly, both cascades in the Malwathu Oya basin have shown higher diversity values.

The same analysis technique was applied to the floral survey data of the Yan Oya basin cascades.

\subsection{Status of the floral diversity - Yan Oya basin}

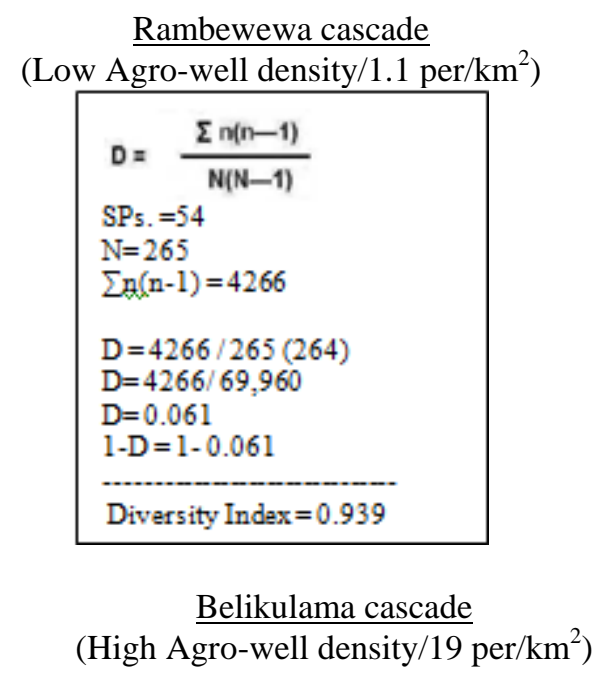

\begin{tabular}{|l|}
$D=\frac{\sum n(n-1)}{N(N-1)}$ \\
$\mathrm{SP}_{5}=52$ \\
$\mathrm{~N}=297$ \\
$\sum \mathrm{n}(\mathrm{n}-1)=3962$ \\
$\mathrm{D}=3962 / 297(296)$ \\
$\mathrm{D}=3962 / 87,912$ \\
$\mathrm{D}=0.045$ \\
$1-\mathrm{D}=1-0.045$ \\
\hline Diversity Index $=0.955$ \\
\hline
\end{tabular}

In the Rambewewa cascade (Low Agro-well density), 54 tree species and 265 individual trees have been recorded. The diversity index was 0.939 . Major reason for the higher diversity was rich diversity level of the 'Highland forest', which represented $56 \%$ of the total diversity. Further $24 \%$ and $20 \%$ of the diversity have been represented in the 'Gasgommana' and 'Kattakaduwa' land uses respectively.

In the Belikulama cascade (High Agro-well density), 52 tree species and 297 individual trees have been recorded. The diversity index was 0.955 . Although this cascade has been a high Agro-well density cascade, the reason for the higher diversity was high tree diversity in 'Agro-well lands'. 65\% of total species has been recorded in Agro-well lands. In addition, $25 \%$ of the total species were recorded from the 'riverine forest strips'. Accordingly, both cascades in the Yan Oya basin too, have shown higher diversity values.

3.3 Comparison of the floral diversity value among high Agro-well density cascades and low Agro-well density cascades of two river basins:

The difference of Simpson's Diversity values between high Agro-well density cascades and low Agro-well density cascades were compared, with the aim of identifying the floral diversity difference.

Table 3: Simpson's diversity index values of high Agro-well density cascades

\begin{tabular}{|c|c|c|}
\hline $\begin{array}{c}\text { Name of the } \\
\text { cascade }\end{array}$ & $\begin{array}{c}\text { Agro-well density } \\
\left(\text { per } / \mathrm{km}^{2}\right)\end{array}$ & $\begin{array}{c}\text { Simpson's diversity Index } \\
\text { value }\end{array}$ \\
\hline Periyakulama & 22 & 0.925 \\
\hline Belikulama & 19 & 0.955 \\
\hline
\end{tabular}

Table 4: Simpson's diversity index values of low Agro-well density cascades

\begin{tabular}{|c|c|c|}
\hline $\begin{array}{c}\text { Name of the } \\
\text { cascade }\end{array}$ & $\begin{array}{c}\text { Agro-well density } \\
\left(\text { per } / \mathrm{km}^{2}\right)\end{array}$ & $\begin{array}{c}\text { Simpson's diversity Index } \\
\text { value }\end{array}$ \\
\hline Halmillawewa & 5.4 & 0.938 \\
\hline Rambewewa & 1.1 & 0.939 \\
\hline
\end{tabular}

The study revealed that both types of cascades have high diversity values, with a small range of difference. Therefore, a significant test was conducted to examine whether these differences are significant or not. 


\section{International Journal of Science and Research (IJSR) \\ ISSN (Online): 2319-7064}

Index Copernicus Value (2013): 6.14 | Impact Factor (2015): 6.391

Table 5: Difference Mean T-Test for Simpson's diversity values

\begin{tabular}{|l|c|c|}
\hline & $\begin{array}{c}\text { High Agro-well } \\
\text { density }\end{array}$ & $\begin{array}{c}\text { Low Agro-well } \\
\text { density }\end{array}$ \\
\hline Mean & 0.9400 & 0.9385 \\
\hline SD & 0.0212 & 0.0007 \\
\hline Number of groups & 2 & 2 \\
\hline
\end{tabular}

$P$ value and statistical significance:

In the two-tailed test, the $\mathrm{P}$ value equal to 0.9344 .

By conventional criteria; this difference was considered to be not statistically significant.

Accordingly, this test revealed that there was no significant difference of floral diversity between the high Agro-well density cascades and low Agro-well density cascades.

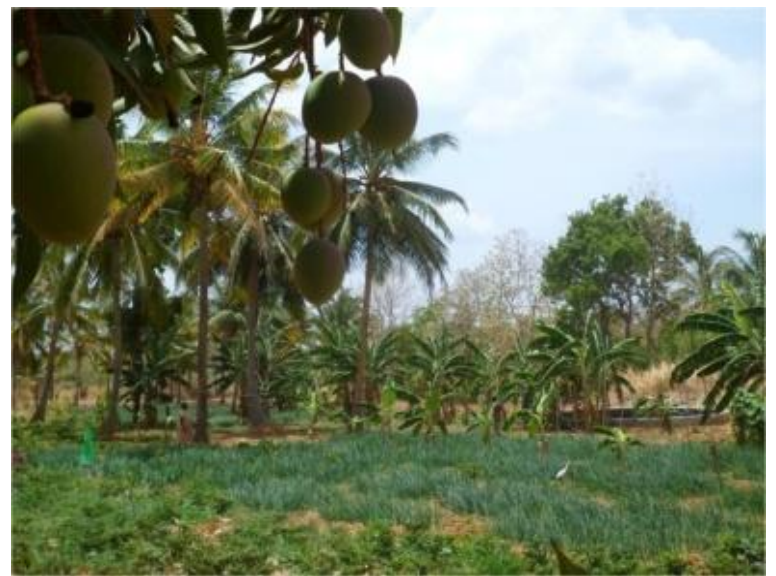

Figure 4: Land use pattern of the Agro-well based lands

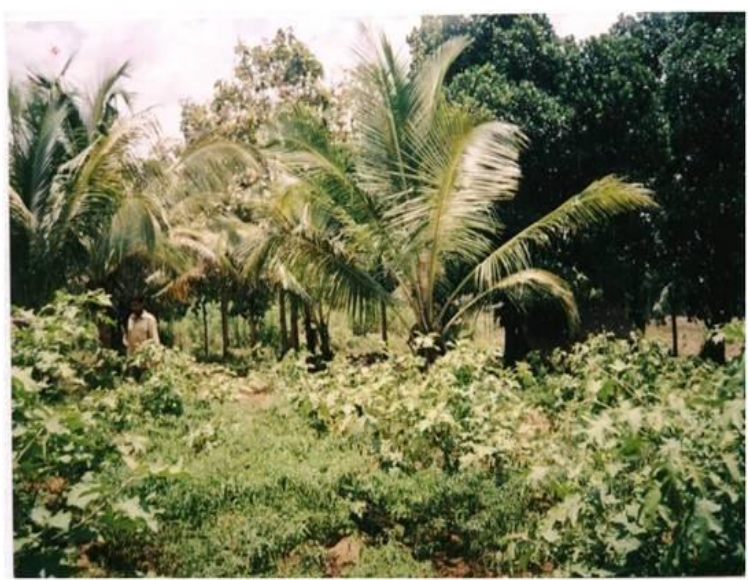

Figure 5: Floral diversity of Agro-well based lands

\section{Conclusion}

The Simpson's Diversity Index values have shown that floral diversity of both types of cascades (Agro-well density low \& high) was high. Within the low Agro-well density cascades in both Malwathu Oya and Yan Oya basin, the floral diversity was high (Simpson's Diversity Index $=0.938$ \& 0.939 ) due to the diversity of "highland forest patches" and "tank reservations". As same as the floral diversity was high, in high Agro-well density cascades (Simpson's Diversity Index $=0.925 \& 0.955$ ). The reason was that floral diversity was rich in "Agro-well based lands" (represented 32\% \& $65 \%$ of diversity), in addition to the riverine forest strips in high Agro-well density cascades. The floral diversity of high Agro-well density cascades and low Agro-well density cascades were not revealed a significant difference, according to the significant test.

According to the above findings, the hypothesis of this test that "Agro-well development causes the degradation of floral diversity in tank cascades" can be conceptually rejected. Consequently, the Agro-well development may not cause degradation of floral diversity in tank cascades.

\section{Future Research Directions}

Few studies have revealed that forest cover of some tank cascades had been removed before the expansion of Agrowells (Perera, 2010) [10]. With the evolution of Agro-well land development in these degraded areas of tank cascades, a number of diverse perennial crop gardens can emerge. Although this results relevant to the current background of highland areas of tank cascades, the stream reservations, and separate ancient tank reservations could be damaged due to the Agro-well land development. Therefore, the attention of the future studies should go to this research area too.

\section{Acknowledgments}

Authors gratefully acknowledge the financial supports given by the following Institutions.

1) International Research Centre, University of Peradeniya, Sri Lanka

Grants Reference Number: InRC/RG/13/06

2) National Centre for Advance Studies in Humanities and Social Sciences, Sri Lanka.

Grants Reference Number:14/NCAS/PDN/Geo/37

\section{References}

[1] R. L. Brohier, "Ancient Irrigation Works in Ceylon", Ministry of Mahaweli Development, Colombo,1934, (pp.1-4)

[2] P.B. Dharmasena, "Integrated Management of Surface and Ground Water Resources in Tank Cascade Systems". In S. Pathmarajah, (ed), Use of Ground Water for Agriculture in Sri Lanka -Symposium Proceedings, Agricultural engineering society of Sri Lanka, Peradeniya, 2002, (pp. 53-65).

[3] P.B. Dharmesena, and R.M. Ranaweera Banda, "Guidelines for Extension Workers to Determine Location-Suitability for Agro-wells". In Annals of the Sri Lanka Department of Agriculture, Peradeniya, 2004.

[4] P.B. Dharmasena, "Small Tank Heritage and Current Problems": Village tank categorization. In M.M. Aheeyar, (Ed.), Small Tank Settlements in Sri Lanka. Kobbakaduwa Agrarian Research and Training Institute, Colombo, Sri Lanka, 2004.

[5] P.B. Dharmasena, "Essential Components of Traditional Village Tank Systems". In: Proceedings of the National Conference on Cascade Irrigation Systems for Rural Sustainability. Central Environmental Authority, Colombo, 2010. 
[6] C.M. Madduma Bandara, "Catchment Eco-systems and Village Tank Cascades in the Dry Zone of Sri Lanka", in The Geo-Journal, Reidel publishing company, Dortrecht, 1985.

[7] C.M. Madduma Bandara, "Village Tank Cascade Systems of Sri Lanka": A Traditional Technology of Water and Drought Management. Proceedings of the third annual workshop on disaster reduction hyperbase Asian application (DRH-Asia), Tokyo, Japan, 2009.

[8] C.M. Madduma Bandara, et al. "Scientific validation of some traditional land and water management practices under Village Tank Cascade Systems", in Economic Review (Vol. 36) People's Bank, Colombo, 2010.

[9] B. Marambe, G. Pushpakumara, P.Silva, "Biodiversity and Agrobiodiversity in Sri Lanka": Village Tank Systems. In: Nakano, S.I., Yahara, T., Nakashizuka, T., Yamamoto, S. (Eds.), Biodiversity Observation Network in the Asia-Pacific Region. Springer, Japan, 2012, (pp. 403-430).

[10] Muditha, Prasannajith Perera, "Land use Changes in Aluth Divulwewa Subwatershed and Emergence of Agro-wells based Agroforestry Systems", (M.Phil Thesis), University of Peradeniya, Peradeniya, 2010.

[11]P.U. Ratnatunga, "Sri Lanka Wewas and Reservoirs Album", Sri Lanka Freedom from Hunger Campaign, Colombo, 1970.

\section{Author Profile}

Muditha Prasannajith Perera is a Senior Lecturer at the Department of Geography, University of Peradeniya, Sri Lanka. He has 12 years of teaching experience and research experience. He has published a number of Magazine Articles, Journal Articles and Books. He is engaging in watershed Management studies, Sri Lankan Hydraulic Civilization based studies and Tank Cascade studies. Currently he is pursuing his $\mathrm{PhD}$ in the field of tank cascade studies.

\section{Corresponding Author Email:}

mudithpp@pdn.ac.lk, mudithpras@gmail.com

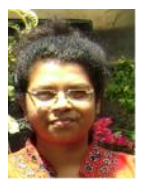

K.W.G. Rekha Nianthi is a senior lecturer at the Department of Geography, University of Peradeniya, Sri Lanka. She obtained a PhD degree in Geography (Applied Climatology) from NEHU, India in 2005. Postdoctoral research has been completed at the University of Minho, Portugal in 2012/13. Her main research interests are Climatological studies and Disaster Management. She is a member of editorial board of the Asian Journal of Environment and Disaster Management. 